Snežana Bogdanović

Mirjana Matović

Visoka škola strukovnih studija za

obrazovanje vaspitača

Novi Sad

bogdanovicsnezana77@gmail.com
UDK: 791.228:37-053.2

Pregledni rad

Primljen: 4. 11.2021.

Prihvaćen: 19.11.2021.

DOI: https://doi.org/10.53406/kd.v9i2.32

\title{
MUZIKA U CRTANIM FILMOVIMA ZA DECU
}

Sažetak: Predškolsko doba je doba ubrzanog i svestranog razvoja deteta. Dečji um je otvoren i spreman da prima različite uticaje. Što je kvalitet i dijapazon pruženih sadržaja veći, to je uticaj na svestrani razvoj deteta značajniji. Muzika se doživljava primarno auditivnim opažanjem, ali i kinestetički $i$ vizuelno. Ukoliko uključimo više kvalitetnih nadražaja, doživljaj muzičkog dela je intenzivniji. Slušanje muzike može biti aktivno, sa namerom i kognitivno slušanje, i pasivno slušanje muzike, gde svesna pažnja biva usmerena i na druge propratne aktivnosti. Primer pasivnog slušanja muzike je posmatranje animiranih filmova sa muzičkom podlogom. Dok dete gleda crtani film, koji svojim vizuelnim i auditivnim nadražajima stimuliše $i$ izaziva receptore, neuronske veze stvaraju u mozgu celinu slike $i$ tona. Muzika naglašava, pojašnjava i razrešava radnju koju nosi animacija, jer je muzika korišćena u podlozi crtanih filmova ostala u trajnoj memoriji kod većine gledalaca, koji su tek kasnije, formalnim obrazovanjem saznali o kojim delima je reč. Danas, zahvaljujući velikom izvoru medijskih sadržaja, deca mogu da biraju dela klasika animacije, što je prilika za nove generacije, čiji se muzički ukus podsvesno formira na delima vrhunske umetničke muzike. Predmet rada je pregled najčešće korišćenih dela umetničke muzike u kratkometražnim i dugometražnim animiranim filmovima za decu. Cilj je ukazivanje na vezu izmedu animacije i muzičke podloge, kao i pregled podataka o gledanju animiranih filmova i prepoznavanju muzike u njima. Rad je namenjen stručnoj javnosti u cilju razvoja strategija za dalju analizu, kontrolu i smislenu primenu muzičkih podloga u različitim medijima.

Ključne reči: predškolski uzrast, dete, muzika, crtani film, muzički ukus, animacija. 


\section{Uvod}

Okruženje u kome dete odrasta ima značajan uticaj na stvaranje temelja za razvoj kulturoloških, estetskih i kulturnih stavova budućeg pojedinca. Pojavom radija, televizije, interneta, vajfaja, striminga i onlajn emitovanja naše virtuelno okruženje počelo je da vrši indirektan uticaj na razvoj ličnosti.

Tehnološki razvoj doveo je do lake dostupnosti, velikog obima i upotrebe virtuelnih informacija. Do deteta lako mogu doći sadržaji koji nisu primereni, prilagođeni niti po kriterijumima usklađeni tako da utiču na svestrani, holistički i integrisani razvoj i dobrobit deteta. Najmlađima su dostupni programi koji celodnevno emituju programske šeme namenjene tom uzrastu, emisije, lutkarske predstave, animirani filmovi, igrane predstave. Kako se deca često opredeljuju za crtani film, razvoj muzičkog ukusa može se dovesti u vezu sa pasivnim slušanjem muzike kao podloge u njegovoj radnji. Oblasti uticaja spoja klasične (visoke) i masovne umetnosti, kao $i$ istraživanje uticaja muzičke podloge na razvoj muzičkog ukusa u kasnijem životnom dobu nisu dovoljno istražene. Upoznavanje sveta umetničke muzike kroz adekvatne medije veoma je značajno. Deca postaju svesna muzike iz crtanih filmova uglavnom tek kada odrastu. Kada im se na određene muzičke numere skrene pažnja, tada uočavaju da su im pojedine melodije bliske i poznate jer su ih nekada slušali.

\section{Značaj muzičkog vaspitanja u ranom uzrastu}

Uticaj muzičkog obrazovanja, sticanja muzičke pismenosti i muzičke kulture nije presudan za postizanje uspeha u školovanju, poslu ili životu, ali ima veliki uticaj na sveukupan razvoj ličnosti. Deca koja se na ranom uzrastu bave muzikom razvijaju osobine ličnosti i veštine koje su značajne za kasnije učenje.

Manasterioti (1978/1979) navodi da je „muzika jedan od značajnijih faktora u formiranju svestrane razvijene ličnosti”. Upoznajući decu sa muzikom, mi delujemo na njihovu svestranost, utičemo na razvoj muzičke estetike, dečje emocije, maštu i stvaralaštvo. Muzička kreativnost drastično se razlikuje u predškolskom dobu u odnosu na kasnije, školsko. U predškolstvu deca muziku doživljavaju kroz improvizaciju, sa više stvaralačkog nadahnuća kroz formu igre i dečje rutine (Matović i Vetnić, 2019). Formalno obrazovanje utiče eventualno na razvoj kategorizacije vidova muzičke prakse kao nečega što se može stvarati, odložiti, ponovo izvesti, preslušati, doživeti (Glover, 2000).

Iako posedovanje apsolutnog sluha nije najvažnije za razumevanje muzike, smatra se retkim darom i javlja se kod 4-8\% profesionalnih muzičara, ali u kulturama u kojima se podstiče rano učenje muzike (Japan) pojava apsolutnog sluha među muzički obrazovanim osobama je oko 50\% (Нишевић и Маринковић, 2013). Kod Doulinga navedeni su autori koji smatraju da se apsolutni sluh može razviti kod svakoga ukoliko se krene sa ranim učenjem - najkasnije do pete, šeste godine (isto, 2013).

Ivanović navodi da prema Kamenovu vaspitanje putem umetnosti ima izuzetan značaj kod predškolske i mlađe školske dece, kao i da je putem umetnosti 
moguće razvijati i oplemenjivati čulnu osetljivost deteta, što je jedan od uslova bogatijeg doživljavanja sveta (Kamenov prema Ивановић, 2019). Kako istražuje Ivanović, Komenski još u 17. veku ističe da saznanje počinje od čula, Ruso smatra da je čulno vaspitanje i vaspitanje čulne osetljivosti važno u prvim godinama života, a Marija Montesori podstiče izlaganje dece velikom broju čulnih uticaja od najranijeg uzrasta (Ивановић, 2019). Stošić smatra da se kao sredstvo bogate senzorne sredine pri slušanju muzike mogu koristiti različiti multimedijalni programi jer se tako izgrađuje sredina koja je najbolja za učenje, eksperimentisanje i istraživanje zvuka, tako da je svakom detetu omogućen razvoj muzičkih sposobnosti kroz njegov individualni tempo učenja (Стошић 2008, prema Ивановић, 2019).

\section{Muzika i animacija}

U vremenu kada rasprostranjenost masovnih medija stvara novu vrstu okruženja i obuhvata veliki broj recipijenata u populaciji dece i mladih, predškolske ustanove i škole ne treba da ignorišu i zaobilaze taj uticaj, već da iskoriste taj materijal za kvalitetnu senzornu stimulaciju dece. Garieli i Tulman ističu da su mediji uopšte, a naročito crtani filmovi, koristan materijal za senzornu stimulaciju dece (prema Ивановић, 2019). Kroz crtane filmove ili animirane bajke deca mogu da uče i sagledavaju različite obrasce ponašanja i da opažaju karakteristike ličnosti. Crtani filmovi bude radoznalost i pomažu deci da se upoznaju sa muzikom. Gledajući ga, deca mogu da percipiraju različite muzičke oblike i žanrove, boje, dinamiku, ritam, različite instrumente i različita zanimanja iz oblasti muzike (Ивановић, 2019).

Pojavom crtanih filmova koji su sinhronizovani muzičkom podlogom započela je posebna era multimedijalnog razvoja. Najpoznatiji autori muzike za crtane filmove živeli su i radili u Sjedinjenim Američkim Državama. Prva autentična animacija nastala je u studiju Volta Diznija (Walt Disney) 1928. godine u animiranom filmu Parobrod Vili.

U više filmskih studija, kao što su Vorner bros (Warner Bros) i Metro Goldvin Majer (Metro-Goldwin-Mayer), shvatilo se da je muzika kičma koja drži animaciju. Kako navodi Ristić u svom članku, Dizni, Metro Goldvin Majer i Vorner bros često su kao podlogu animaciji koristili remek-dela klasične muzike, koja je podsvesno ostala u pamćenju velikom broju ljudi širom sveta. Upravo zato će u ovom radu analiza primera korišćenja umetničke muzike biti usmerena na filmska ostvarenja studija koji su imali statistički najveću gledanost, a time i najveći uticaj na najširu publiku.

\section{Muzika u kratkometražnim crtanim filmovima}

U zlatnom periodu kratkometražnih animiranih filmova najproduktivniji kompozitor je bio Karl Stoling (Carl Stalling), koji je napisao muziku za preko šest stotina crtanih filmova. Kao potvrdu teze da pasivno slušanje ostavlja duboko utisnute primere u našoj svesti, Ristić (2019) citira Leonarda Maltina, autora i kritičara koji u svom dokumentarnom filmu Crtani filmovi: Iza crtaća/tonova 
(Looney Tunes: Behind the Tunes) opisuje kako je veliki deo njegovog muzičkog znanja potekao upravo od Karla Stolinga, ali tako da on toga nije bio svestan. Tokom odrastanja gledao je crtane filmove svakodnevno i upamtio je Listovu (Franz Liszt) Mađarsku rapsodiju, jer se često pojavljivala. Kompozitor Stoling je maestralno uklapao muzičke žanrove, kompozicije i zvučne efekte kako bi omogućio podršku i isticanje dramskih akcenata u animacijama.

Komponovanjem autentične muzike spajao je različite muzičke žanrove i originalne muzičke literature. Ristić takođe navodi i iskaz Danijela Goldmarka (Daniel Goldmark), koji u uvodu za knjigu Melodije za crtaće (Tunes For „Toons”) deli svoje iskustvo sa podsvesno utisnutom melodijom koju je tek kasnije prepoznao kao Mocartovu Sonatu za klavir u C-duru KV 545, a koju je usvojio kao petogodišnjak. Kasnije, u toku formalnog obrazovanja, prepoznaje i Šubertovu kompoziciju Vilinski kralj. Za njega je bilo značajno otkriće to što je muziku spoznao na taj način i time ne samo stekao znanja o umetničkoj muzici, nego i o ostalim muzičkim stilovima i pravcima.

Filmska kompanija Vorner bros je 1940. godine prvi put emitovala crtani film sa Duškom Dugouškom u glavnoj ulozi. On je poznat po glavnim ulogama u serijalima Vesele melodije (Merry Melodies) i Lude melodije (Looney Tunes). Crtani film Korni koncert (A Corny Concerto), koji je nastao kao parodija na Diznijevu Fantaziju, emitovan je 1943. godine, u trajanju od 7 minuta i 58 sekundi. U uvodnim scenama kao podloga se čuje Koncert za klavir br. 1 Petra Iljiča Čajkovskog, a zatim se nastavlja sa dva segmenta Štrausovog valcera Priče iz Bečke šume i valcera Na lepom plavom Dunavu. Prepoznatljiv je po sceni tri labudića i patka koji pokušava da im se pridruži pri plivanju po jezeru.

Crtani film Zečja rapsodija (Rapsody Rabbit) emitovan je 1947. godine u trajanju od 7 minuta i 33 sekunde. Bavi se oslikavanjem atmosfere na koncertu klasične muzike i ukazuje na njenu strogu etikeciju. Duško Dugouško je predstavljen kao pijanista koji interpretira Mađarsku rapsodiju Franca Lista. U crtanom filmu se pored nekoliko melodija popularne muzike čuju i segmenti Vagnerovog (Richard Wagner) Zigfrida, kao i karakterističan napev Figaro iz Rosinijeve (Gioachino Rossini) opere Seviljski berberin.

U crtanom filmu Uštogljeni zec (Long Haired Hare) iz 1949. godine prikazuje se „rat” između umetničke i popularne muzike, čuju se melodije popularne muzike i odlomci iz Seviljskog berberina Đoakina Rosinija i Lučije od Lamermura Gaetana Donicetija (Gaetano Donizetti). Ovaj crtani film je primer maestralnosti Karla Stolinga koji je, prema Goldmarku, pored originalne muzike koju je komponovao, vešto uklopio značajna dela poput Largo al factotum, 1. čin Seviljskog berberina, sekstet Chi mi frena in tal momento iz 2. čina Lučije od Lamermura (Lucia di Lammermoor, Gaetano Donizetti), drugu temu iz Preludijuma Vagnerove Loengrine (Lohengrin 2nd theme from the Prelude to Act III, Richard Wagner), kao i uvertiru iz operete Franca fon Supea Lepa Galatea (Die schöne Galathee the overture, Franz von Suppé). Sva ova dela je vrhunski uplitao sa delima popularne "narodske” muzike kao što su : Kišna noć u Riu Artura Švarca (A Rainy Night in Rio, Arthur Schwartz), Moja devojka je dama Barnija Fagana (My Gal is a HighBorn Lady, Barney Fagan) i Kada Juba svira rumbu na tubi Hermana Hupfelda (When Yuba Plays the Rumba on the Tuba, Herman Hupfeld). 
Sledeće maestralno delo spoja animacije i umetničke muzike uključuje Vagnerovo stvaralaštvo. Crtani film Šta ima u operi, šefe? (What's Opera, Doc?) emitovan je 1957. godine, u trajanju od 6 minuta i 33 sekunde. Animaciju prati muzika iz ciklusa opera Riharda Vagnera Prsten Nibelunga (Der Ring des Nibelungen). U uvodnoj sceni koristi se uvertira Letećeg Holandanina (Der fliegende Holländer), prati je tema iz Valkire (Die Walküre), a zatim Zigfridov zov roga. Muzička linija se ponovo vraća na uvertiru Letećeg Holanđanina i prelazi na uvertiru iz Tanhojzera (Tannhäuser) i temu Pilgrimovog hora (Pilgrims' Chorus). Finale se razvija uz treći čin Valkire i vraćanje na uvertiru Tanhojzera. Muziku je aranžirao Milt Frenklin (Milt Franklyn).

Ovaj crtani film se od 1994. godine nalazi na prvom mestu od 50 najboljih crtanih filmova svih vremena, a 1992. godine ga je Kongresna biblioteka Sjedinjenih Američkih Država proglasila „kulturno, istorijsko ili estetski važnim” i svrstala ga u Nacionalni filmski registar, čime je postao prvi crtani film kojem je dodeljena takva čast (Beck \& Friedwald, 1989).

Još jedan crtani film koji oslikava atmosferu na koncertu klasične muzike i u podtekstu kritikuje uštogljenost i zatvorenost visokog sloja društva koje posećuje koncerte klasične muzike jeste crtani film Duško Dugouško (Baton Bunny). Emitovan je 1959. godine, u trajanju od 7 minuta. Muzička podloga animaciji je kompozicija Jutro, podne i veče u Beču Franca fon Supea (Ein Morgen, ein Mittag und Abend in Wien, Franz von Suppé).

Pored filmske kompanije Vorner bros, kompanija Metro Goldvin Majer je u svojim kratkometražnim animiranim filmovima pomoću junaka Toma i Džerija (Tom and Jerry) kroz više decenija oslikavala i naglašavala remek-dela klasične muzike, isticala muzičko obrazovanje, muzičku kulturu i upoznavala veliki broj dece i odraslih ne samo sa poznatim delima nego i sa epohama i značajnim kompozitorima.

Primer animiranog filma sa tematikom klasične muzike jeste crtani film Mačji koncert (The Cat Concerto). Emitovan je 26. 04. 1947. godine, u trajanju od $7 \mathrm{mi}$ nuta i 49 sekundi. Muziku je komponovao i adaptirao Skot Bredli (Scott Bradley). U crtanom filmu Tom svira Mađarsku rapsodiju br. 2 Franca Lista, međutim, u stalnoj međusobnoj borbi, Džeri na kraju završava koncert i dobija aplauz. Ova epizoda je osvojila prestižnu nagradu Oskar za najbolji kratkometražni animirani film i 1994. godine se našla na 42. mestu od 50 najboljih epizoda Tom i Džeri crtanih filmova.

Sledeći primer je crtani film Johan miš (Johann Mouse), koji već svojim naslovom u originalu asocira na ime kompozitora Johana Štrausa. Muziku je komponovao Skot Bredli, inspirisan delima Johana Štrausa. Crtani film je emitovan 1953. godine, u trajanju od 7 minuta i 57 sekundi. To je 75 . animirani film franšize i poslednji koji je osvojio nagradu Oskar za kratkometražni film. Radnja se odvija u Beču u 19. veku u kući Johana Štrausa i u palati austrijskog cara. Tokom animacije muzičku podlogu na klaviru izvodi Jakob Gimpel. Ceo crtani film je prožet muzikom Štrausovih valcera.

U septembru 1950. emitovan je crtani film Tom i Džeri u holivudskoj dvorani (Tom and Jerry in the Hollywood Bowl), u kom Tom diriguje orkestrom uvertiru operete Slepi miš (Die Fledermaus) Johana Štrausa II. 
Crtani film Niko me ne voli (Snowbody Loves Me) emitovan je 1964. godine, u trajanju od 8 minuta. Muziku je komponovao Eugen Podani (Eugene Poddany), inspirisan delima Frederika Šopena (Frederic Chopin). U crtanom filmu se mogu čuti teme iz Etide op. 10, br. 12 (Revolutionary Etude), Velikog valcera u Es-duru (Grande Valse Brillante in E-flat major) i Fantazije-impromptu (Fantasie-Impromptu).

O sole mjau (O-Solar-Meow) je još jedan crtani film u kojem se kao kompozitor potpisuje Eugen Podani, ovaj put inspirisan izvornom napolitanskom pesmom iz 1898. godine $O$ sole mio. Emitovan je 1967. godine i traje 6 minuta i 46 sekundi.

U zlatno doba crtanih filmova zapadne kulture autori, reditelji i producentske kuće radili su na beskompromisnom kvalitetu sadržaja koji će se emitovati. Neretko je kroz prizmu animiranih kratkih filmova emitovana poruka, kao i kritika društva i društvenih odnosa (Gabler, 2006).

Postoji još primera kratkometražnih animiranih filmova koji se mogu analizirati jer sadrže segmente originalne umetničke muzike, međutim, pomenuti primeri su najčešće emitovani u svetu i na našem medijskom prostoru.

\section{Muzika u dugometražnim crtanim filmovima}

Dugometražni animirani filmovi su svoje zlatno doba doživeli u filmskom studiju Volta Diznija 1940-ih godina, sa povremenim usponima i padovima. Iako kada se spomene muzika u animiranim medijima pomislimo na vezu klasične muzike i dugometražnih crtanih filmova, taj odnos je veoma mali kada se uporedi upotreba klasične muzike u kratkometražnim crtanim filmovima. U većini dugometražnih animacija muzika je autentična. Komponovana je za određeni film i iako se osete uticaji velikana kompozicije, ipak predstavlja originalno i autentično delo kompozitora novije generacije.

Kao i u primerima kratkometražnih animiranih filmova, kompanija Dizni je unela inovacije i postavljala više ciljeve. Nakon prvog dugometražnog crtanog filma u boji koji je imao potpunu muzičku podlogu - Snežane i 7 patuljaka, koji je emitovan 1937. godine i Pinokia, koji je emitovan 1940. godine, kompanija Dizni 1940. godine stvara Fantaziju (Fantasia). U stvaranju ovog remek-dela učestvovalo je preko 1000 umetnika i tehničara. Animacija koja je u savršenom skladu sa muzikom nastala je posle dugog promišljanja i negovanja ideje Volta Diznija još iz 1930. godine. Emitovan je 1941. godine u trajanju od 2 sata i 5 minuta.

Film se sastoji iz osam segmenata koje u potpunosti određuju izabrana dela umetničke muzike. Sedam kompozicija izvodi Filadelfijski orkestar, kojim diriguje Leopold Stokovski (Leopold Stokowski), a kompozitor i muzički kritičar Dim Tejlor (Deems Taylor) imao je ulogu ceremonijara i pojašnjavao je gledaocima svaki segment koji će gledati. Zvuk je snimljen pomoću višestrukih audio-kanala i prvi je film koji je reprodukovan pomoću Fantasaunda, što ga čini prvim filmom sa stereo-ozvučenjem.

Prvi segment predstavlja animaciju Tokate i fuge u d-molu Johana Sebastijana Baha (Toccata und Fuge in d-Moll, Johann Sebastian Bach). Animacija je apstraktna i u potpunosti oslikava muziku - bojom, valerom i akcentima u plavoj i zlatnoj 
boji, kojima se naglašava svaki ton i takt u melodiji. Animatori koriste linije, oblike i formacije koje oslikavaju zvuk, ritam i melodiju.

U drugom segmentu se koriste odlomci iz baleta Krcko Oraščić Petra Iliča Čajkovskog. Animacija nas vodi kroz godišnja doba od leta, preko jeseni do zime. Kroz plesne koreografije prikazane su vile, ribe, cveće, pečurke i lišće. Korišćeni su stavovi Krcka Oraščića op. 71a: Ples šećerne vile, Kineski ples, Ples flauta, Arapski ples, Ruski ples i Valcer cveća.

Treći segment je Čarobnjakov šegrt Pola Dukasa (Paul Dukas). Uz prepoznatljivu, ali ipak modernizovanu animaciju, Dizni studio uključuje kratkometražni u dugometražni film. Priča i kompozicija su inspirisane Geteovom (Goethe) poemom iz 1797. godine Čarobnjakov šegrt (Der Zauberlehrling).

Četvrti deo vizuelno oslikava nastanak planete Zemlje, pojavu prvih živih bića, nastanak i nestanak dinosaurusa, a animaciju potpuno verno prate odlomci iz baleta Posvećenje proleća Igora Stravinskog (Rite of Spring, Igor Stravinsky).

Nakon četvrtog segmenta orkestar pravi pauzu, muzičari se razilaze i na ekranu se pojavljuje naslov Fantazija. Po povratku muzičara, čuje se kratak džez intermeco, a zatim se na ekranu pojavljuje animacija zvuka, koja menja boju i oblik u zavisnosti od boje i jačine zvuka.

Peti segment oslikava svet grčke i rimske mitologije. Uz Betovenovu (Ludwig van Beethoven) Pastoralu (Symphony No. 6 Pastoral Op. 68: I. Allegro ma non troppo; Op. 68: II. Andante molto mosso; Op. 68: III Allegro; Op. 68: IV Allegro; Op. 68: $V$ Allegretto), mitska bića kentauri, pegazi, jednorozi i kupidoni proslavljaju festival u čast Bahusa - boga vina, ali ih prekida vrhovni bog Zevs, koji stvara oluju i gađa ih munjama.

Jedan od najpoznatijih segmenata Fantazije nastao je na muzičku temu Ples satova iz opere Đokonda Amilkarea Ponkijelija (La Gioconda, Amilcare Ponchielli). Animacija prati vremensku liniju: prvo se pojavljuju nojevi - balerine koji simbolizuju jutro, zatim nilski konj - primadona i njene pomoćnice za podne, nakon toga slonovi koji simbolizuju veče i na kraju trupa aligatora koji simbolizuju noć. Finale prikazuje sve likove kako zajedno plešu dok se palata ne sruši.

Poslednji segment blisko prati priču koju je kompozitor Musorgski ( $\mathrm{Mu}-$ ssorgsky) pisao na partituri dok je komponovao delo Noć na golom brdu (Night on Bald Mountain). Animacija oslikava ples zlih duhova i demona sve dok ih ne otera zvuk anđeoskih zvona koja se čuju u zoru. Na kraju se čuje pesma Ave Marija Franca Šuberta (Ave Maria, Franz Schubert) u horskom i solo izvođenju (Barrier, 2003). Kao remek-delo animiranog filma, Diznijeva Fantazija je 1998. godine svrstana na 58. mesto najboljih američkih filmova i izabrana je za čuvanje u Nacionalnom filmskom registru Sjedinjenih Američkih Država kao „kulturno, istorijsko ili estetsko dobro" (Allan, 2000).

Dve godine kasnije, 1942. godine, Diznijev studio emituje dugometražni animirani film Bambi, u kom je originalnu muziku komponovao Frenk Čerčil (Frank Churchill), a Edvard Plam (Edward Plumb) aranžirao i komponovao na osnovu originalne Čerčilove partiture (Goldmark, 2002). Iako nisu korišćena izvorna dela klasika, neosporan je uticaj Ravela i Stravinskog.

Poslednji dugometražni crtani film kompanije Dizni u kome je korišćena originalna muzika klasika je Uspavana lepotica, emitovana 1957. godine. Džordž 
Bruns (George Bruns) je komponovao i adaptirao balet Uspavana lepotica Petra Iliča Čajkovskog. Uz nekoliko numera koje su komponovane za potrebe filma, u izvođenju renomiranih operskih izvođača, animacija je rađena tako da se uskladi prema melodiji. Delo je snimano u Berlinu 1958. godine, u izvođenju Minhenskog simfonijskog orkestra (Goldmark, 2002).

Volt Dizni je kroz svoje stvaralaštvo pokušao da oplemeni generacije ljudi, shvatio je da njegova dela imaju snažan uticaj na veliki broj konzumenata, i tu svoju moć je iskoristio na pravi način. Iako po struci nije bio muzičar, imao je istančan osećaj kako da publici predstavi potpuni doživljaj priče, a to je bez kvalitetne muzičke podloge bilo nemoguće.

U čitavoj eri dugometražnih animiranih filmova još se samo dva filma baziraju na muzici velikana klasične muzike Petra Iliča Čajkovskog. Oba filma su nastala u produkciji Juniversal pikčers (Universal Pictures Home Entertaiment), kanadsko-američke filmske kompanije, u saradnji sa firmom Matel (Mattel), kojoj je izdavanje bilo bazirano na DVD i VHS nosačima i nije bilo bioskopskih premijera. Prvi film franšize Barbi (Barbie) jeste film inspirisan baletom Krcko Oraščić P. I. Čajkovskog. Muziku je aranžirao Arni Rot (Arnie Roth), a snimio Londonski simfonijski orkestar. Film je emitovan 2001. u trajanju od 78 minuta. Barbi i Krcko Oraščić (Barbie in the Nutcracker) u potpunosti prati radnju koju diktira muzika.

Barbi od Labudovog jezera (Barbie of Swan Lake) je drugi dugometražni kompjuterski animirani film koji nas, takođe, vodi kroz partituru i libreto baleta $\mathrm{La}$ budovo jezero P. I. Čajkovskog. Film je emitovan 30. 09. 2003. godine u trajanju od 83 minuta. Muziku za film je aranžirao i komponovao Arni Rot, koristeći se originalnim delom Čajkovskog (Fitzpatrick, 2001).

U većini dugometražnih animiranih filmova korišćena je originalna muzika koja je komponovana za dati film i ta činjenica ne umanjuje vrednost ovih filmova. Sve je češća upotreba muzičkih lista koje sadrže muziku iz crtanih filmova, što se može potvrditi statističkim pregledima različitih muzičkih kanala. Vrednost, uticaj i značaj muzičke podloge važni su za animaciju, ali imaju veliki značaj i u sferi podsvesnog slušanja muzike. Umetnici i stručnjaci koji rade u filmskoj industriji svesni su ovog fenomena i, kako ističe Goldmark, brzo su shvatili da je muzika „kičma animacije” (Goldmark, 2002). Hojt Kurtin navodi da je komponovanje za animirani film vrhunac umeća i da ako neko ume da komponuje za crtani film, onda može da komponuje bilo šta. Umeće da se muzikom prati brza promena slika, raspoloženja, jačine i karaktera tona, zvučnih efekata, žanrova i muzičkih pravaca jeste upravo ono što u velikoj meri i određuje animaciju. Bez tona animacija ne bi mogla da oživi.

\section{Zaključak}

Postavlja se pitanje da li ranim uticajima možemo doprineti većem obuhvatu i postavljanju kvalitetnijeg temelja za razvoj muzičkih sposobnosti i veština, kao i za celokupan razvoj ličnosti deteta. Da li ulaganje u sveobuhvatno muzičko obrazovanje, naravno prilagođeno didaktičkim principima, možemo shvatiti kao investiranje u budućnost. Multimedijalno okruženje pretpostavlja veliki uticaj na 
razvoj estetskih, moralnih i kulturoloških normi, te je važno da odrasli budu upućeni u njegovu strukturu. Kako su deca ranog uzrasta najviše programski upućena na animirane medije, tako i pažnja odraslih treba da bude usmerena ka kreiranju kvalitetnog podteksta koji se emituje u pozadini.

Muzika u animiranim medijima zauzima važnu poziciju. Počev od izolovanog zvuka koji pruža podršku animaciji do umetničkih dela muzike koja utiču na ukupan vizuelni, auditivni i emotivni doživljaj animirane priče, spoj muzike i animacije je neraskidiv. Danas je teško zamisliti kako bi izgledala animacija bez tona i da li bi uopšte mogla dostići ovakav vid popularnosti. S druge strane, i umetnička muzika pomoću animacije izlazi iz okvira stroge etikecije i pronalazi put do širokog auditorijuma.

Roditelji i danas deci puštaju klasike animacije poput crtanih filmova Miki Maus, Duško Dugouško i Tom i Džeri, iako nisu dostupni u onoj meri u kolikoj su bili prethodnim generacijama. Pronalaze posebne kanale na kojima se emituju klasični crtani filmovi od DVD diskova, USB kartica, preko virtuelnih skladišta poput gugl diska i jutjub kanala. Licencirani proizvodi i nemogućnost pristupa preko kanala koje deca lako koriste - TV programi i jutjub kanal - pružaju prepreku da deca sama dođu do željenih rezultata ili do slučajnog odabira, kako se to dešava sa ostalim nezaštićenim i nelicenciranim primerima.

U predškolskim ustanovama se može raditi na osnaživanju vaspitača i obrazovanju u pravcu važnosti podsvesnog nadražaja kod dece, ali se istovremeno mora raditi na obrazovanju odraslih u okruženju deteta, kao i na sistemskom i profesionalnom jačanju svih struktura društva kako bi se kvalitetan programski sadržaj ponovo uključio u svakodnevnu strukturu multimedijalnog okruženja. Da bi se ovaj plan ostvario, potrebno je iskoristiti sve resurse koje nam multimedije pružaju, te ojačati i povezati formalno obrazovanje sa prethodnim iskustvom pojedinca. Odrastanje uz Mikija, Duška, Toma i Džerija dragoceno je iskustvo i ne treba ga uskratiti novim generacijama. Muzika koja nosi priču animiranih slika je vanvremenska i razume se na svim jezicima. Neophodno je negovati kulturu i u uslovima koje diktiraju novi mediji, a kako se kroz animirane filmove lako i trajno usvajaju dela vrhunske umetničke muzike, tim pre se mora raditi na očuvanju i negovanju animiranih filmova koji čuvaju te tradicionalne vrednosti. 


\section{Literatura}

Allan, R. (2000). Walt Disney and Europe: European Influences on the Animated Feature Films of Walt Disney. Indiana University Press.

Barrier, M. (2003). Hollywood Cartoons: American Animation in Its Golden Age. Oxford University Press.

Beck, J., \& Friedwald, W. (1989). Looney Tunes and Merrie Melodies: A Complete Illustrated Guide to the Warner Bros. Cartoons. New York: Henry Holt and Company.

Fitzpatrick, E. (2001, August 25). Barbie Stars in Artisan's „Nutcracker”. Billboard, 113(34). Nielsen Business Media, Inc.

Gabler, N. (2006). Walt Disney: The Triumph of American Imagination. New York City: Alfred A. Knopf Inc.

Glover, J. (2000). Children Composing, 4-14. London: Routledge.

Goldmark, D., \& Taylor, Y. (2002). The Cartoon Music Book. Chicago, Illinois: A Cappella Books - Chicago Review Press.

Matović, M. i Vetnić, N. (2020). IT tehnologije u razvoju muzičke pismenosti deteta predškolskog uzrasta. Pedagoška stvarnost, 66(1), 28-42.

Ristić, S. (2019). Spoj visoke i masovne kulture: klasična muzika i crtani fim. https://www.casopiskus.rs/spoj-visoke-i-masovne-kulture-klasicna-muzika-icrtani-film/

Ивановић, М. (2019). Савремени медији у настави музике - дидактичке специфичности и потенцијали. У: С. Маринковић (ур.), Зборник радова 22(21) (227-242). Ужице: Универзитет у Крагујевцу, Педагошки факултет.

Манастериоти, В. (1978/1979). Улога музике у формирању свестране личности. Музичко васпитање, 4(1). Нови Сад: Предшколска установа „Радосно детињство”.

Нишевић, С. и Маринковић, Л. (2013). Психологија детињства и адолесценције. Нови Сад: Mediterran.

Стошић, А. (2008). Могућности примене мултимедијалне технологије у настави музичке културе. Иновације у настави, XXI(1), 88-97. 


\author{
Snežana Bogdanović \\ Preschool Teachers Training College, Novi Sad \\ Mirjana Matović \\ Preschool Teachers Training College, Novi Sad
}

\title{
MUSIC IN CHILDREN'S CARTOONS
}

\begin{abstract}
Preschool age is the time of children's rapid and versatile development. The child's mind is open and ready to receive various influences. The higher is the quality and range of the provided content, the more significant is the impact made on the child's development. Music is experienced primarily through auditory perception, but also kinesthetically and visually. If we include more quality stimulation, the experience of a musical piece will be more intensive. Listening to music can be active, intentional and cognitive, and passive, with conscious attention directed towards other activities. A good example of passive listening to music is watching animated movies with background music. When children watch cartoons, which stimulate and provoke brain receptors by visual and auditory stimuli, neuron connections in the brain create the unity of sound and image. Music emphasizes, clarifies and resolves the action carried by animation, and the music used in the background of animated movies remains in permanent memory of most people. Only later, through formal education, they find out what those musical pieces were. Today, thanks to a large source of media content, children can choose works by great animators. This way, new generations are able to develop their musical taste subconsciously, with pieces of best art music. The subject of this paper is to determine the most frequently used pieces of art music in cartoons and animated feature films for children. The aim is to point to the connection between animation and background music, to collect information on watching animated films and recognizing their musical impact. The results are intended for professionals in order to develop strategies for further analysis, control and meaningful application of background music in various media.
\end{abstract}

Key words: child, music, preschool age, musical taste, animation, cartoon movies. 